\title{
A Brief History of Urban Water Supply in the Antiquity
}

\author{
L.W. Mays ${ }^{1}$, D. Koutsoyiannis ${ }^{2}$, and A. N. Angelakis $^{3}$ \\ ${ }^{1}$ Arizona State Univ., Tempe, Arizona 85287-5306, USA, mays@asu.edu \\ 2 Department of Water Resources, School of Civil Engineering, National Technical University of Athens, Heroon \\ Polytechneiou 5, GR 157 80, Zographou, Greece, dk@itia.ntua.gr \\ ${ }^{3}$ Institute of Iraklio, National Agricultural Research Foundation, 71307 Iraklio, Greece, angelak@nagref-her.gr
}

\begin{abstract}
A brief history of ancient water supply techniques for urban areas from the earliest civilizations through the Roman times is presented. Throughout the history of urban centers, a sufficient water supply has been the backbone of each city. All sources of water, rivers, lakes, springs, underground sources, and rainwater collection, were exploited for urban supply starting from the earliest civilizations. The specific choice was depending upon the civilization, the geomorphology, the topography, and the local climatic and hydrological conditions. No large-scale lifting techniques were available; thus, water was transferred from the source by aqueducts from a higher altitude. Cisterns used for collection of rain water and wells for drawing groundwater were very well developed since the Bronze Age. During historical times, Greeks and later Romans reached a high level of water supply technologies that greatly influenced modern achievements in water engineering and management.
\end{abstract}

Keywords Ancient civilizations; aqueducts; cisterns; urban water distribution.

\section{INTRODUCTION}

Humans have spent most of their history as hunting and food gathering beings. Only in the last 9000 to 10000 years they discovered how to grow crops and tame animals. Such revolution probably first took place in the hills to the north of Mesopotamia. From there the agricultural revolution spread to the Nile and Indus Valleys. During this agricultural revolution, permanent villages replaced a wandering existence. About 6000 to 7000 years ago, farming villages of the Near East and Middle East became cities. During the Neolithic age (ca. 5700-2800 BC), the first successful efforts to control the flow of water were driven by agricultural needs (irrigation) and were implemented in Mesopotamia and Egypt. Remains of these prehistoric irrigation canals still exist.

Urban hydraulic systems are dated at a later stage, in the Bronze Age (ca. 2800-1100 BC). There are several astonishing examples of urban water systems from about the mid-third millennium BC. Mohenjo-Daro, a major urban centre of the Indus Civilization, developed a sophisticated system for water supply and sewage. Water came from more than 700 wells and supplied not only domestic demands but also a system of private baths and a Great Bath for public use (Jansen, 1989). The Mesopotamians were not far behind (Adams, 1981). An example is the city of Eshnunna (80 km northeast of the present Baghdad) dated in the same period, where archaeological excavations exposed sewers constructed of brick, with laterals connecting to houses (Gray, 1940). In the Sumerian city of Nippur the excavations exposed clay pipes as well as tee- and angle-joints. Rainwater harvesting and collection in cisterns for urban water supply was practiced at about the same period in Jawa in northeastern Jordan (Abdel Khaleq and Alhaj Ahmed, this issue). Another collection system, this time for groundwater, was developed in Persia, again in the same period (Hassan, 2003). This is the well-known "qanat" - a subterranean system of tunnels connecting wells and dug using vertical shafts, designed to collect and transport water, sometimes over long distances, from highlands to low-lying farming land.

Amazing characteristics of the latter technology are its application over a tremendously long period up to modern times and the durability of the systems constructed. For instance, in Iran, over millennia, 22,000 qanat units were constructed, comprising more than 270 thousand kilometers of 
underground channels. In the 1960s, $75 \%$ of all the water used in that country for irrigation and domestic consumption was provided by such systems (Wulff, 1968). Over the centuries, the technology was transferred to all civilizations and become known with different names such as 'karez' (Afghanistan and Pakistan), 'kanerjing' (China), 'falaj' (United Arab Emirates) and 'foggara/fughara' (North Africa). A “foggara” in Algeria is shown in Fig. 1. According to UNESCO recommendations, some of those projects are protected as monuments of world heritage.
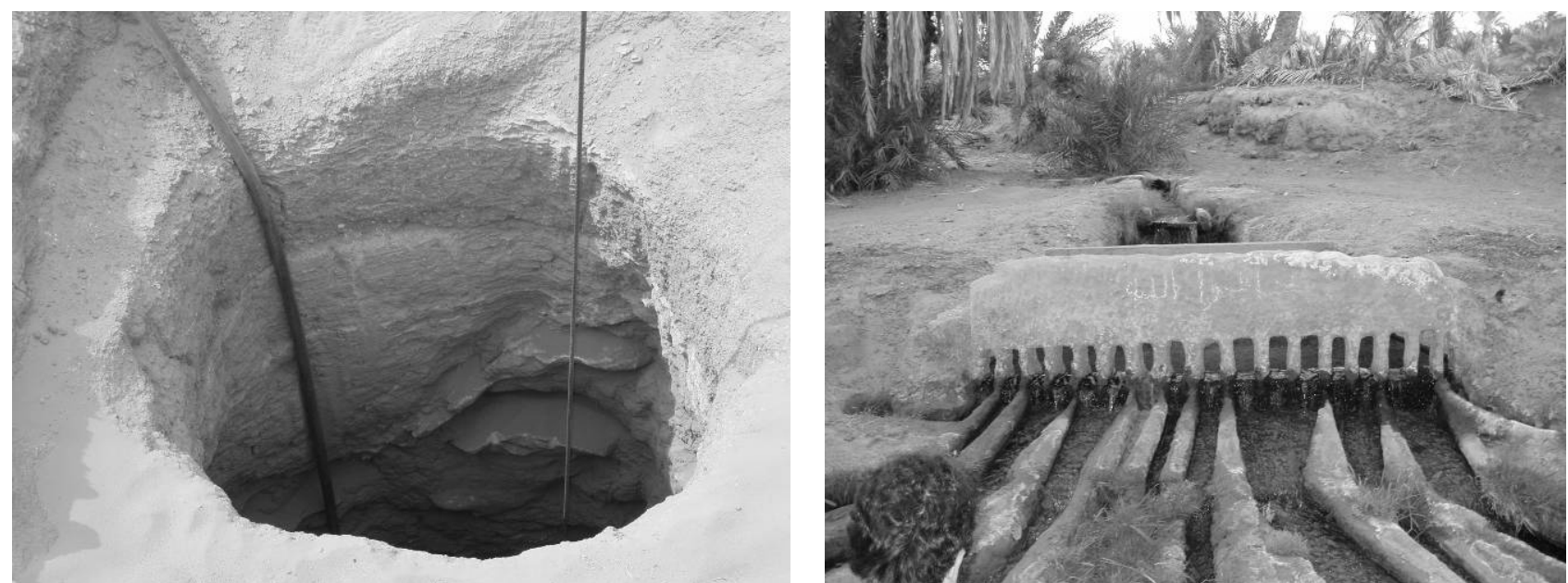

Figure 1 A foggara at Adrar, Algeria: (left) shaft; (right) distribution and metering weir at the foggara outlet.

Starting from the Bronze Age, hydraulic technologies were developed further in Greece during several stages of the Greek civilization. New more advanced water technologies were also invented there, with a peak in the Hellenistic period that follows Alexander the Great, during which they spread over a geographical area from Greece to India to the east and Egypt to the south. The Romans, whose Empire replaced the Greek rule in most part of this area, inherited the technologies and developed them further also changing their application scale from small to large and implementing them to almost every large city. The Greek and Roman water technologies are not only a cultural heritage but are the underpinning of modern achievements in water engineering and management. The durability of some of the constructions that operated up to modern times, as well as the support of the technologies and their scientific background by written documents enabled these technologies to pass to modern societies despite regressions that have occurred through the centuries (i.e. in the Dark Ages).

\section{THE GREEK SYSTEMS}

\section{The Minoan and Mycenaean civilizations}

The island of Crete, Greece, was first inhabited shortly after $6000 \mathrm{BC}$ and within three thousand years it had became the largest Neolithic settlement in the Aegean Sea. During the Bronze Age the Minoan civilization was developed and reached its culmination as the first Greek cultural miracle of the Aegean world. The Minoan and Mycenaean settlements (in Crete and mainland Greece, respectively) developed and applied various technologies for collecting, transporting and using water from rainfall, and surface and ground resources (Koutsoyiannis et al., 2007a).

Water cisterns. In ancient Crete the technology of surface and rain water storage in cisterns for water supply was very well developed and was continuously used up to modern times. One of the earliest Minoan cisterns was found in the center of a pre-palatial house complex at Chamaizi dated in the turn from the $3^{\text {rd }}$ to the $2^{\text {nd }}$ millennium BC (Fig. 2, left). The house complex there is located on the top of a hill and its rooms are set around a small open court with a deep circular rock-cut 
cistern with dimensions of $3.5 \mathrm{~m}$ deep and $1.5 \mathrm{~m}$ diameter lined with masonry in its upper part (Davars, 1976). Four of the earliest structures which may be considered as large cisterns on Minoan Crete were built in the first half of the 2nd millennium BC (the time of the first Minoan palaces) at Pyrgos-Myrtos (Ierapetra), Archanes, Tylissos and Zakros (Cadogan, this issue). At the famous Phaistos palace, a cistern was depended on precipitation collected from rooftops and courts; a supplementary system of water supply was needed to satisfy the needs of water supply, especially in the particular area where agriculture was intensively practiced. Thus, water was probably used from wells in an area southwest of the palace, rich in ground and surface water, and Ieropotamos River located northern, at the foot of the Phaestos hill (Gorokhovich, 2005). Also, in Malia, a site lying in a narrow plain between mountains and the sea, cisterns were present on the high grounds above the palace (Moody, 1996). Those cisterns were associated with small canals collecting surface water from rainfall and from mountain streams (Viollet, 2003). It is therefore possible that cisterns were the origins of canals or aqueducts supplying the palace and the surrounding city with water.

Cisterns were also discovered in excavations in mainland Greece which were constructed by Myceneans in the $13^{\text {th }}$ century BC. The most interesting element of the cisterns found in Mycenae and Tiryns is their underground placement at depths up to $18 \mathrm{~m}$ below ground level (Showleh, this issue).

Groundwater and wells. Knossos, the best known Minoan settlement, had wells since the Early Minoan time (Muller 1996). During the period of the first palace (ca. 1900-1700 BC), several wells were used for drawing drinking water. At least six such wells have been reported (Evans, 19211935). Their depth did not exceed $20 \mathrm{~m}$ and their diameter was no more than $5 \mathrm{~m}$ (Buffet and Evrard, 1950). The most important and best known has depth of about $12.5 \mathrm{~m}$ and diameter $1.0 \mathrm{~m}$. In the Zakros palace a well-spring is located near the southeast corner of the central Court; steps, now damaged by visitors' feet, led down into the chamber. The Palekastro town was also depended on groundwater. Several wells have been discovered so far with depths ranging from 10 to $15 \mathrm{~m}$ (Fig. 2, right). The sites of Palekastro and Zakros are located in the eastern part of the island of Crete and it seems that this particular part of Crete was rich in groundwater, now sub-saline.
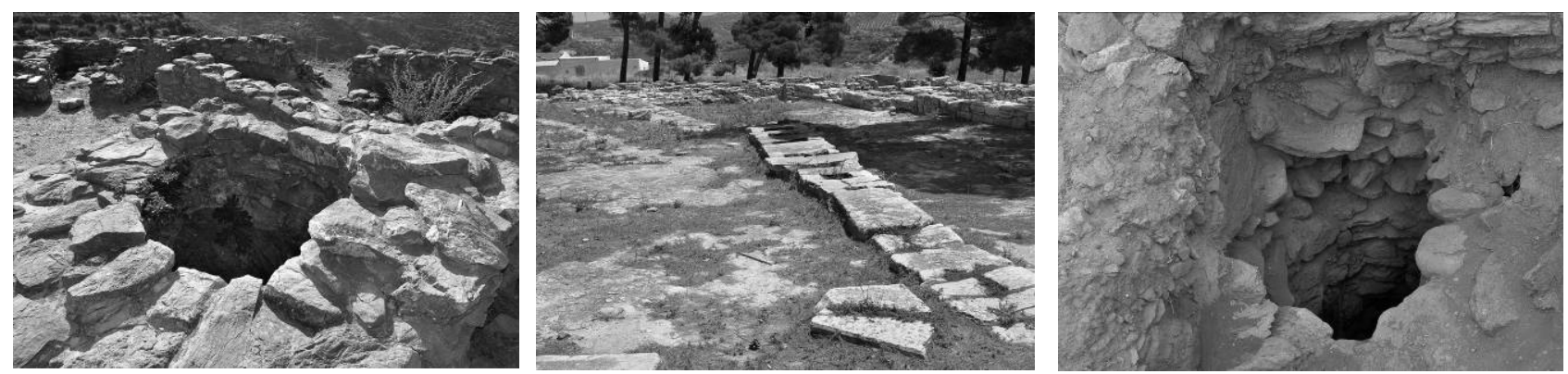

Figure 2. Minoan water collection and transfer projects: (left) cistern at the House complex in the vicinity of the village Chamaizi, near the town of Sitia; (middle) part of the aqueduct at the ancient town of Tylissos; and (right) well used for water supply at the Palekastro town.

Aqueducts. In ancient Crete the technology of transporting water with aqueducts was very well developed due to the mountainous terrain. The Minoan inhabitants of Knossos depended partially on wells, and mostly on water provided by Kairatos River to the east of the low hill of the palace, and on springs. Indications suggest that the water supply system of the Knossos palace initially relied on the spring of Mavrokolybos, a limestone spring located $450 \mathrm{~m}$ southwest of the palace (Angelakis et al., 2006). In later periods with the increase of population other springs were used in longer distances. A second example of aqueduct was found in Tylissos. Parts of the masonry aqueduct (Fig. 2, middle), with the main conduit at the entrance of the complex of houses, and other secondary systems led the water to a cistern, namely cistern D, which is dated at ca. 1425- 1390 . 
Water distribution systems. The advanced water distribution systems were based on the use of pipes. In the Knossos palace, water distribution was provided through a network of terracotta piping located beneath the floors in depth that varies from a few centimeters up to $3 \mathrm{~m}$ (Evans, 19211935). Similar terracotta pipes were found in some other Minoan sites, such as at Tylissos carrying water from the spring of Aghios Mamas where other pipes have also been traced with possible distillers. Terracotta pipes have also been spotted at Vathypetro, as well as in the "Caravanserai" (Guest House), southern of the Knossos palace whereas some have also been found scattered in the countryside. Alternatively, other pipes made of cypress, which was in abundance, must have been used as suggested from wooden parts of the $2 \mathrm{~km}$ long aqueduct of the Mycenaean palace at Pylos in southwest Peloponnesus (Taylour, 1983). Pipes made of wood were used later during the Roman period in northern Europe and especially in Germany (Hodge, 2002) and even in modern times.

Sewer and drainage systems. In addition to water distribution systems, palaces were also equipped with elaborate storm drainage and sewer systems. Some palaces had toilets, much resembling present day ones, with flushing systems operated either manually (by pouring water in a flushing conduit) or by connection to storm drainage conduits.

Recreational structures. Fountains, aquaria and other water related structures for recreation must have decorated the Minoan palaces as suggested by several indications. Among these, perhaps the most remarkable is provided by the fresco fragments from the "House of Frescoes" which seems to depict a “jet d'eau” (Angelakis and Spyridakis, 1996).

\section{Archaic and classical periods}

In the archaic and the classical periods of the Greek civilization, aqueducts, cisterns, and wells were built similar to Minoan and Mycenaean ones. However, the scientific and engineering progress during those stages enabled the construction of more sophisticated structures. One of the most famous is the tunnel of Eupalinos (530 BC) in the Samos Island, the first deep tunnel in history that was dug from two openings with the two lines of construction meeting at about the middle of the distance. The construction of this tunnel, which served the water supply of Samos, was made possible by the progress in geometry and geodesy that was necessary to implement two independent lines of construction that would meet (Koutsoyiannis et al., 2007a).

There are several other known aqueducts in Greek cities as water supply was regarded an essential and necessary infrastructure of any city (Tassios, this issue). For safety reasons, aqueducts were always subterranean, either tunnels or trenches. At the entrance of the city, aqueducts would branch in the city and would feed cisterns and public fountains in central locations. Along in the bottom of trenches or tunnels of aqueducts, pipes usually from terracotta were laid, allowing for protection. One, two or more pipes in parallel were used depending upon the flow to be conveyed. The terracotta pipe segments (20 to $25 \mathrm{~cm}$ in diameter) fit into each other and allow access for cleaning and maintenance by elliptic openings (Fig. 3 ) that were covered by terracotta covers.

Water transferred by aqueducts typically originated from springs, often formed on karstic geological formations. The existence of natural springs was a definite criterion for the selection of an area to settle. For example, the Acropolis at Athens that has been the focus of settlement starting with the earliest times, in addition to providing defensive capabilities, had also an aquifer and a spring named "Clepsydra". With the intensified urban development and the increase of population the natural springs could not cover the water demand. The increasing water deficit was then remedied by transferring water from distant springs by aqueducts, digging wells and constructing cisterns for rainwater. In Athens all these alternatives coexisted: the Peisistratean aqueduct, 
constructed in the end of the $6^{\text {th }}$ century BC was accompanied with a plethora of wells and later cisterns. But all this system with public and private elements was not easy to manage. Therefore, the need for a wise and effective management emerged. In Athens this was achieved both by legislative and institutional tools. Starting from the beginning of the $6^{\text {th }}$ century BC, Athens developed an amazing sustainable management system with balance among the public and private sectors (Koutsoyiannis et al., 2007a).

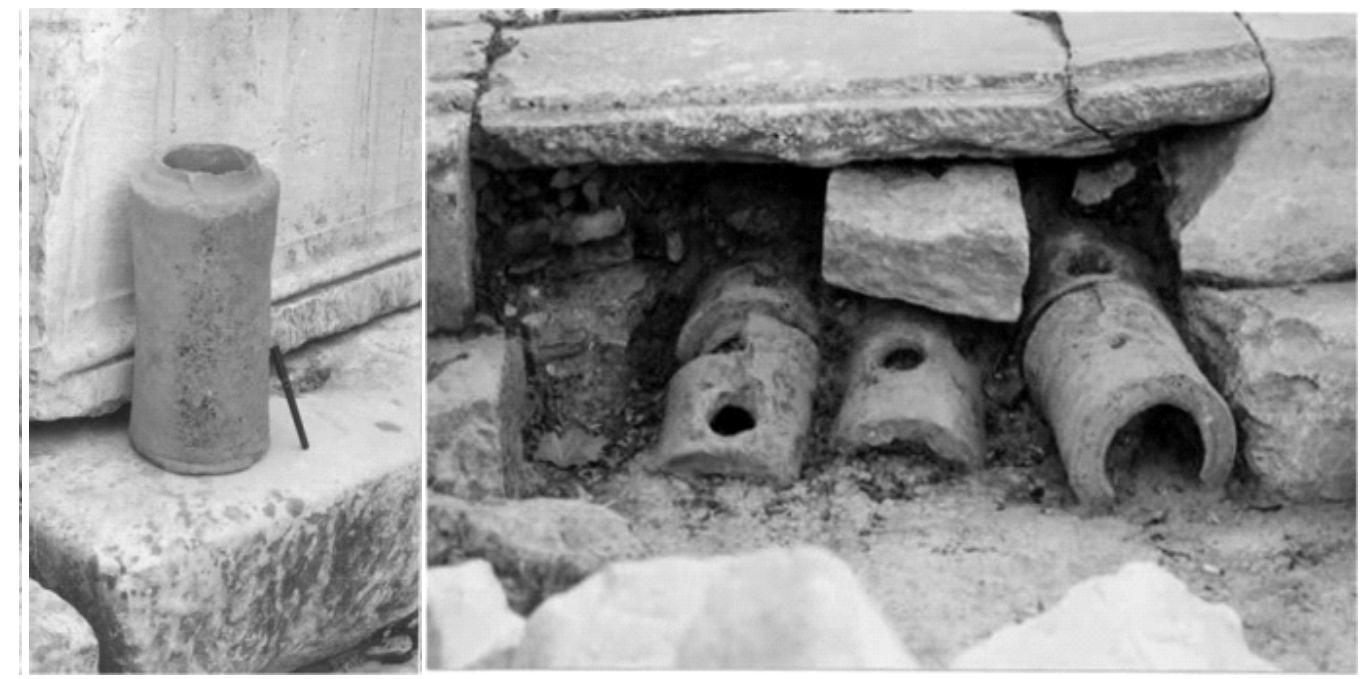

Figure 3 Terracota pipes at the Ephesus, Ionia.

Naturally the technologies developed in Greece were transferred to the Greek colonies both to the east in Ionia (Asia Minor, where now is Turkey) and to the west in the Italian peninsula, Sicily and other Mediterranean sites, most of which were founded during the archaic period. An excellent example of this was the founding of Syracuse (on Sicily) as a colony of Corinth in 734 BC. Among the many things transferred from the Corinthian culture, such as language, religion, government, and farming was the water management. As Crouch (1993) points out, the transfer of knowledge about managing water was facilitated by the similarity of geology and climate between the two sites. From the $8^{\text {th }}$ to $1^{\text {st }}$ century BC the knowledge of locating and collecting water was coupled with the increasing knowledge of transporting both fresh and used water.

The geology of site, with the earlier and later limestone layers above clay created an abundance of water. The Arethusa spring, located at the edge of the sea, was the first settlement on Ortygia (Crouch, 1993). The water supply came from many surface and subsurface openings in the limestone, particularly where the limestone lies above impermeable strata such as marl. The series of grottoes above the Greek theater (Fig. 4) was probably a major factor in the development of Syracuse, because the early Greeks found water flowing here. After time, possibly a couple centuries, water found a new path further downhill and to cover increased demand (because of increased population) new supplies to this location were developed, using the same outlets. These were the Galermi and the Ninfeo aqueducts. The water elements of Syracuse during the Greek times were later expanded during the Roman times.

\section{Hellenistic period}

Later, during the Hellenistic period, further developments were done by Greeks in hydraulics, such as in the construction and operation of aqueducts, cisterns, wells, harbours, water supply systems, and sewerage and drainage systems. During that period the political and economic situation changed leading to much more architectural development and urban beautification, of which aqueducts played a major role. The lifestyle and sanitation standards were advanced, as testified for instance by the extended use of baths and toilets (Antoniou, this issue). The progress in science 
during the Hellenistic period provided a new technical expertise. Hellenistic aqueducts usually used pipes, as compared to the Roman masonry conduit. Furthermore, following the classical Greek tradition, the aqueducts continued to be subterranean for security reasons (not no be exposed to aliens, e.g. in case of war) but also for the safety of the construction during earthquakes which are frequent in the area. This again contrasts the Hellenistic technology with the later Roman technology, whose apparent characteristic is the use of the arches and aqueduct bridges (see below).

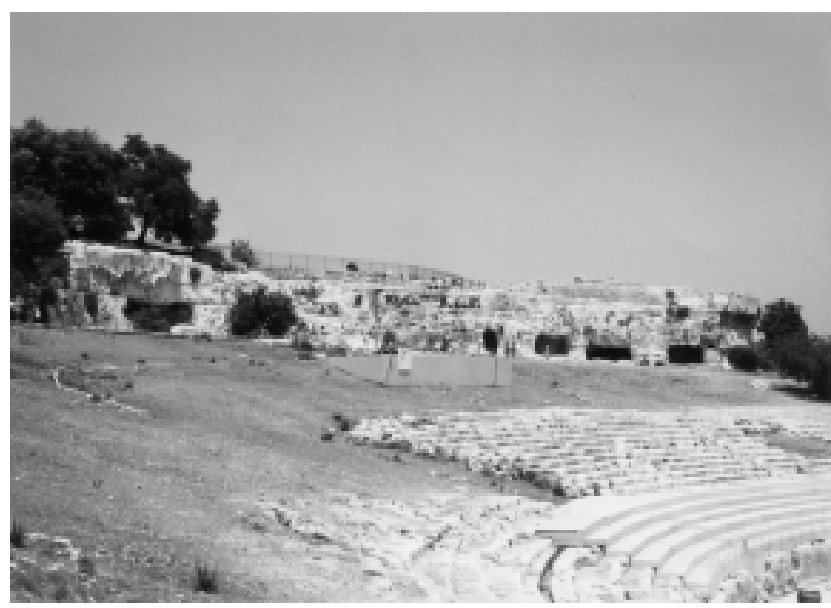

(a)

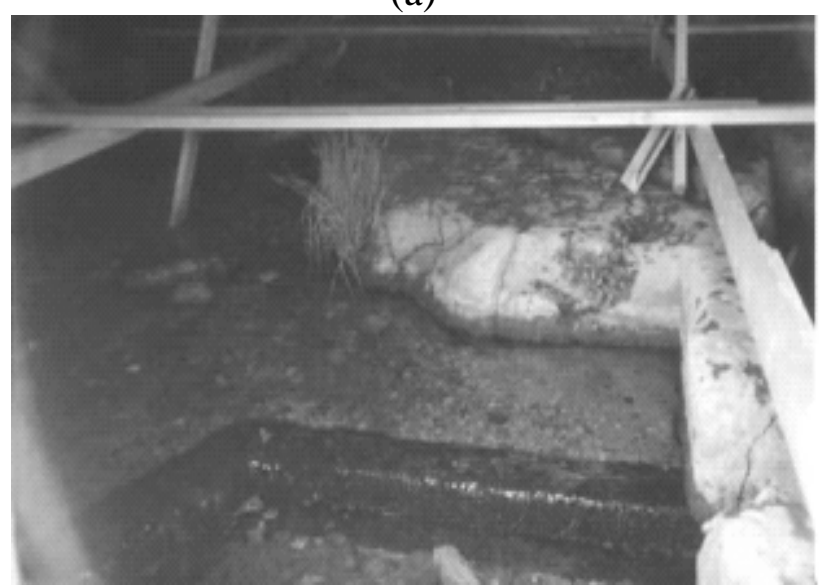

(c)

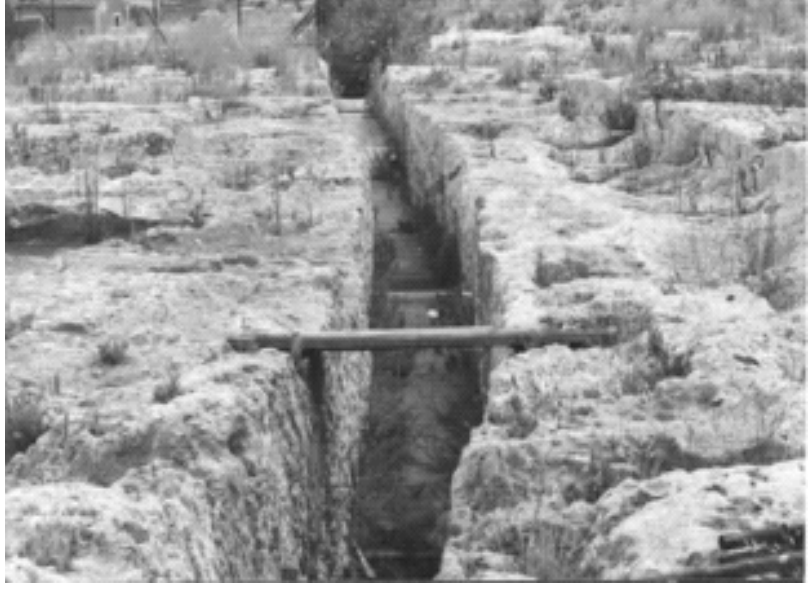

(b)

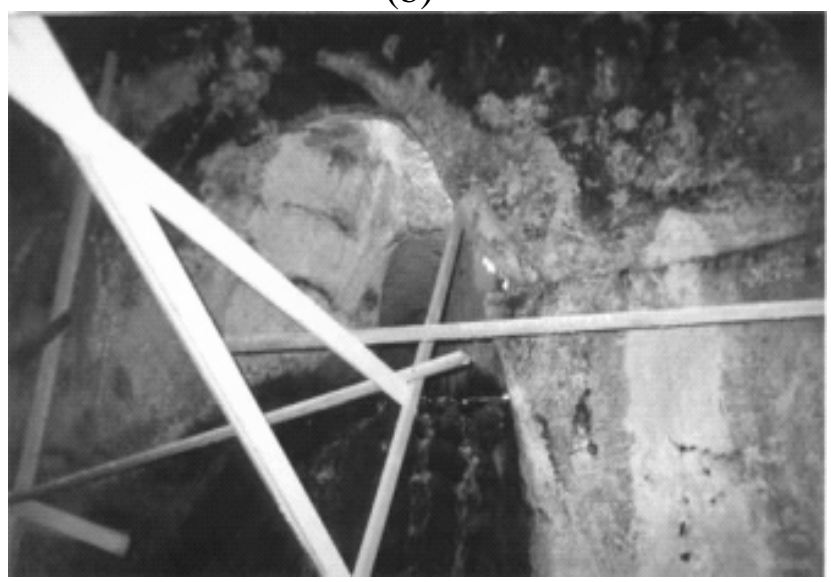

(d)

Figure 4 Water system at Syracuse: (a) Greek theatre in Syracuse along grotto formation in background from where water flowed; (b) view of aqueduct above grottoes; and (c) and (d) outlets of Galermi and Ninfeo aqueducts inside grotto formation, respectively.

Greek aqueducts generally operated by free surface flow. However, during the Hellenistic period, the scientific progress in understanding hydrostatics and the water and air pressure (due to Archimedes, Hero of Alexandria and others; Koutsoyiannis et al. 2007a and this issue) allowed the construction of inverted siphons at large scales (lengths of kilometers, hydraulic heads of hundreds of meters). Thus, Hellenistic engineers constructed inverted siphons to convey water across valleys in aqueducts of several cities including Ephesus, Methymna, Magnesia, Philadelphia, both Antiochias, Blaundros, Patara, Smyrna, Prymnessos, Tralleis, Trapezopolis, Apameia, Akmonia, Laodikeia and Pergamon (Tassios, this issue). These siphons were initially built by stone pipes (square stone blocks to which a hole was carved) or terracotta. However, the need for higher pressures naturally led to the use of metal pipes, specifically from lead. Thus, one of the aqueducts of Pergamon includes an inverted siphon of length exceeding $3 \mathrm{~km}$ with a maximum pressure head of about $180 \mathrm{~m}$, whose pipes were from lead (Tassios; this issue). 


\section{THE ROMAN SYSTEMS}

\section{Characteristic technological elements}

The Romans built what can be called mega water supply systems including many magnificent structures. Water flowed by gravity through enclosed conduits (specus or rivus), which typically were underground, from the source to a terminus or distribution tank (castellum). Above ground aqueducts were built on a raised embankment (substructio) or on an arcade or bridge. Settling tanks (piscinae) were located along the aqueducts to remove sediments and foreign matter. Secondary lines (vamus) were built at some locations along the aqueduct to supply additional water. Also subsidiary or branch lines (ramus) were used. At distribution points water was delivered through pipes (fistulae) made of tile or lead. These pipes were connected to the castellum by a fitting or nozzle (calix). These pipes were placed below ground level along major streets.

To properly discuss Roman water supply we must be aware of the treatises of Vitruvius, De Architectura (Morgan 1914), and Sextus Julius Frontinus, De aquaeductu urbis Romae (translation 1973). The following quote from Vitruvius describes how the aqueduct castellum worked (as presented in Evans, 1994). "When it (the water) has reached the city, build a reservoir with a distribution tank in three compartments connected with reservoir to receive the water, and let the reservoir have three pipes, one for each of the connecting tanks, so that when the water runs over from the tanks at the ends, it may run into the one between them.”

To acquire a general picture of Roman technologies, several Roman water supply systems are briefly described in the subsections below.

\section{The water system of aqueducts and dams at Merida, Spain}

In 25 BC Emerita Augusta (Merida, Spain) became a colony and a century later the Romans had built a water supply system including three aqueducts, two of which were supplied by dams (the Cornalvo dam and the Proserpina dam shown in Fig. 5, left, middle). The three aqueducts were the Cornalvo aqueduct (enters on the east side of Merida), the Proserpina aqueduct (enters on the northeast side of town), and the Las Thomas aqueduct (from springs on the north and northeast side of Merida). The Cornalvo aqueduct was built first and was about $17 \mathrm{~km}$ long. Cornalvo dam is an earthen dam approximately $194 \mathrm{~m}$ long, $20 \mathrm{~m}$ high, and has an $8 \mathrm{~m}$ dam crest width. A few remains of the Cornalvo aqueduct are visible near the present day bull ring.
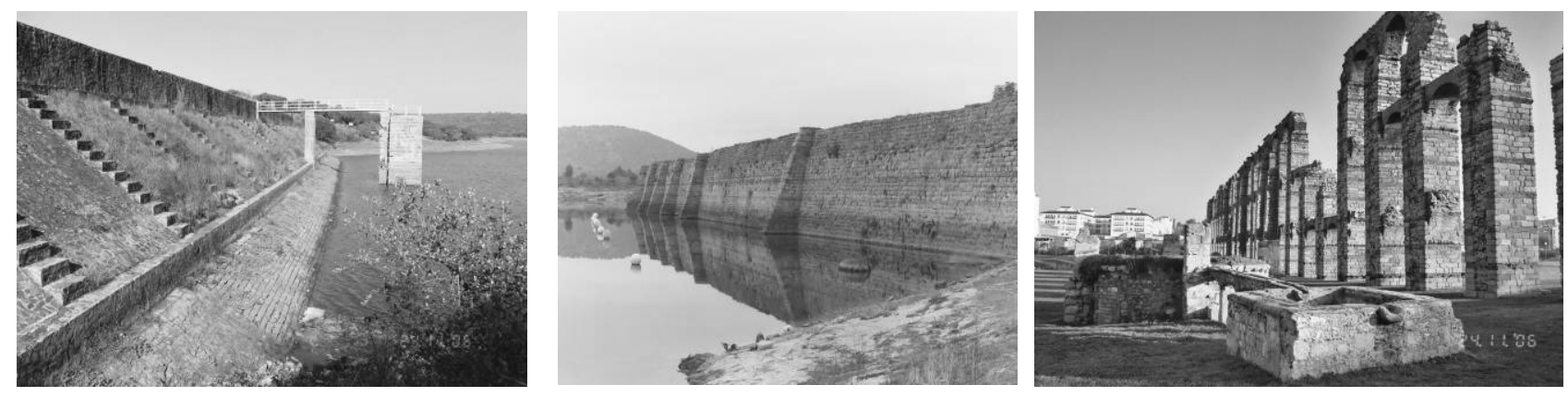

Figure 5 Water system at Merida: (left) Cornalvo Dam near Merida; (middle) Proserpina Dam near Merida; and (right) Los Milagro aqueduct bridge across the Rio Albarregas in Merida.

The Las Thomas aqueduct included an aqueduct bridge $1600 \mathrm{~m}$ long (across the Rio Albarregas), of which only three pillars (16 m high) remain. Materials from this aqueduct bridge were used by the Arabs in the $16^{\text {th }}$ century to construct the San Lazaro aqueduct bridge. The Proserpina dam, an earthen dam $427 \mathrm{~m}$ long and $12 \mathrm{~m}$ high, located north of Merida, supplied water to the 10-km long Los Milagros aqueduct. This aqueduct entered the town on the north side with an aqueduct bridge 
over the Rio Albarregas, also referred to as the Los Milagros (the miracles) by the Spanish, with a maximum height of $30 \mathrm{~m}$.

\section{The aqueduct system of Lyon, France (ancient Lugdunum)}

Four aqueducts were used to supply water to the ancient city of Lugdunum. There were the Mont d'Or, the Yzeron, the Brevenne and the Gier. The aqueduct of the River Gier (Fig. 6) was the longest and the highest of the four aqueducts. Approximately half of the aqueduct was subterranean with at least nine tunnels, four siphons, and over 80 manholes.

\section{The aqueduct system of Rome}

The aqueduct system in Rome evolved over a 500-year time period, with the first aqueduct, the Aqua Appia, being constructed around 313 BC (Fig. 7). This system, with eleven aqueducts eventually supplied water to Rome mostly from springs. However, two were supplied from the Anio River and one from Lake Alsietinus. All the major eastern aqueducts entered Rome at the Porta Maggiore.
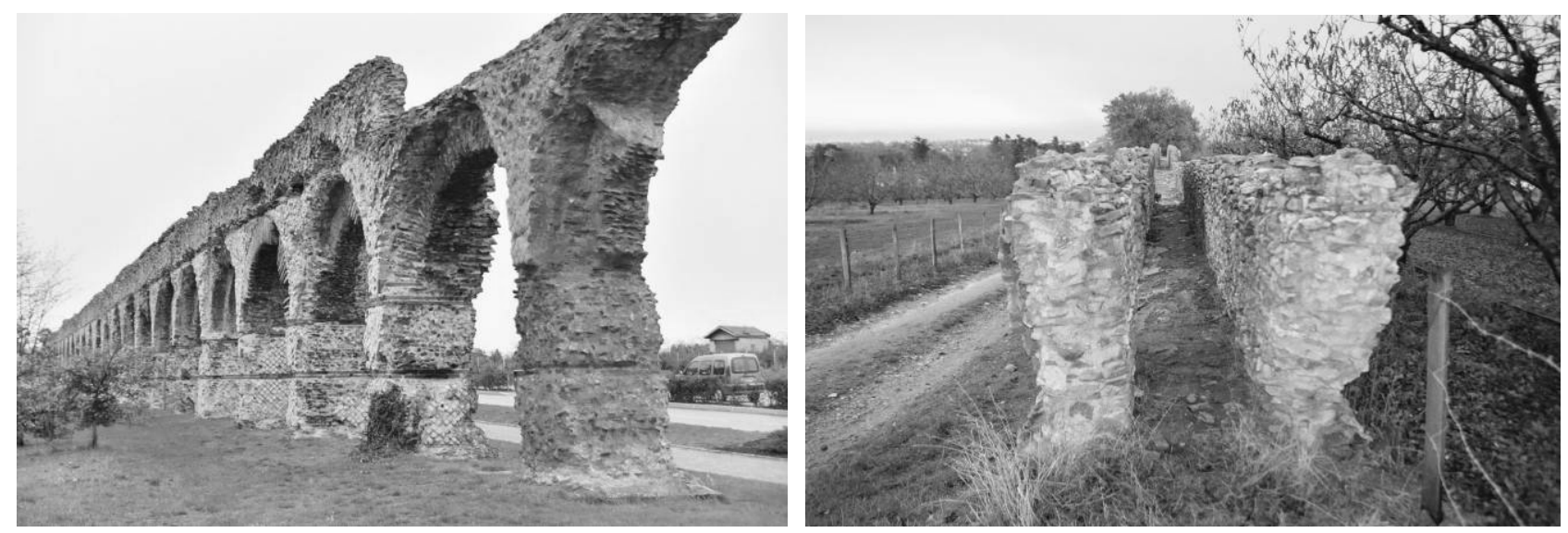

Figure 6 Aqueduct of the River Gier near Chaponost, France.
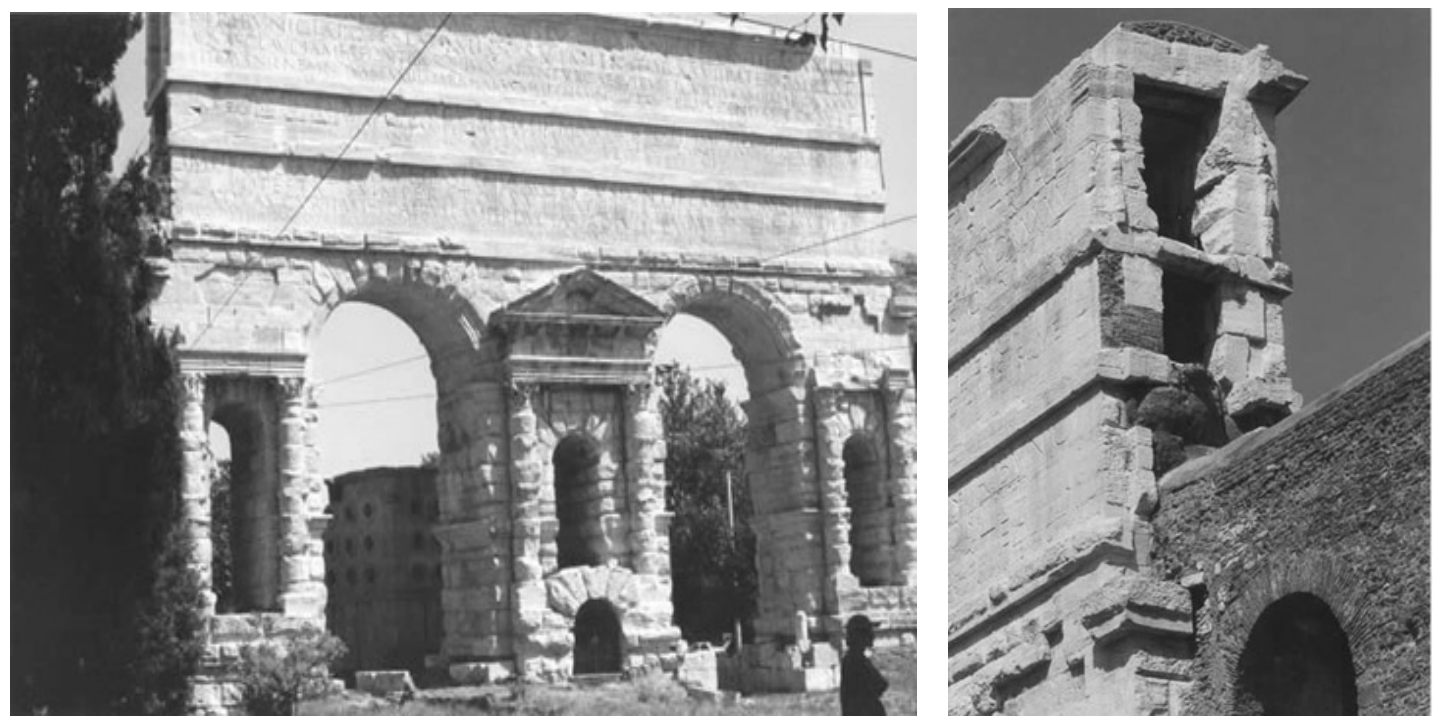

Figure 7 Aqueducts of Rome: (left) view of Porta Maggiore (double-arched gate) on the Aurelian Wall where all the eastern aqueducts entered Rome; and (right) aqueducts Claudia (top) and the Anio Novus (bottom) above the Porta Maggiore 


\section{The aqueduct of Nimes (ancient Nemausus)}

The aqueduct of Nemausus (built around $20 \mathrm{BC}$ ) conveyed water approximately $50 \mathrm{~km}$ from Uzes to the castellum divisorium in Nimes (Fig. 8). From an engineering point of view this was a remarkable construction project in that the elevation difference over the length of the aqueduct was only $17 \mathrm{~m}$, making the slope only $0.34 \mathrm{~m} / \mathrm{km}$ (see also Fonder and Xanthoulis, this issue). The Pont du Gard (Fig. 8, left) is one of the most spectacular aqueduct bridges ever built and is the most photographed in the world.

\section{The urban water supply system in Pompeii}

The Pompeii water supply system is a representative Roman urban water distribution system (Fig. 9). The Greco-Roman city of Pompeii is located on the Bay of Naples, south-southeast of Mt. Vesuvius in Italy. Pompeii is one of the most significant proofs of the magnificence of Roman civilization that was originally founded by Greek colonists probably around the $9^{\text {th }}$ to $8^{\text {th }}$ century BC. The city was influenced by others including the Etruscans for almost 50 years (until 474 BC), after which, it came back under Greek rule. During the $5^{\text {th }}$ century it became part of the Samnite area of expansion, during which time it saw tremendous growth. Pompeii became under the influence of Rome after three long and bitter wars around 290 BC. In 80 BC it became a Roman colony with the name of Colonia Cornelia Veneria Pompeii. Pompeii had a flourishing economy and widespread affluence after it became a colony that experienced a devastating earthquake in about 62 AD a few years later on August 24, 79 AD. Mt Vesuvius erupted and destroyed the city.
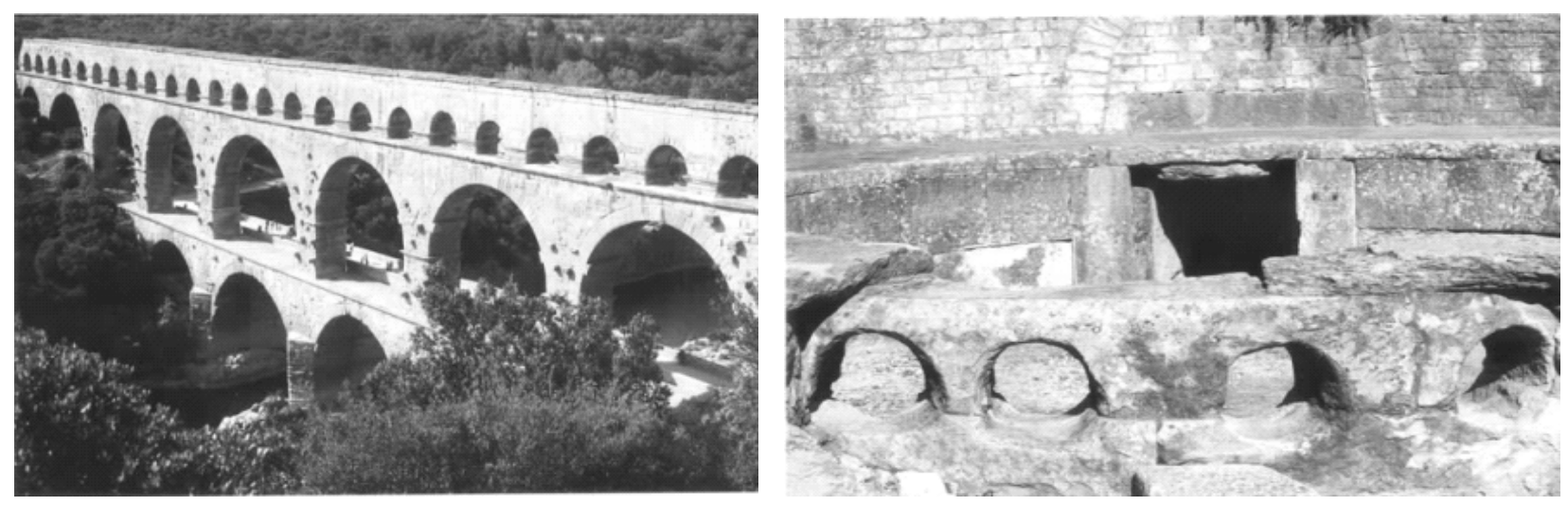

Figure 8 Water system of Nemausus: (left) Pont du Gard aqueduct bridge; and (right) castellum divisorium in Nimes, France.
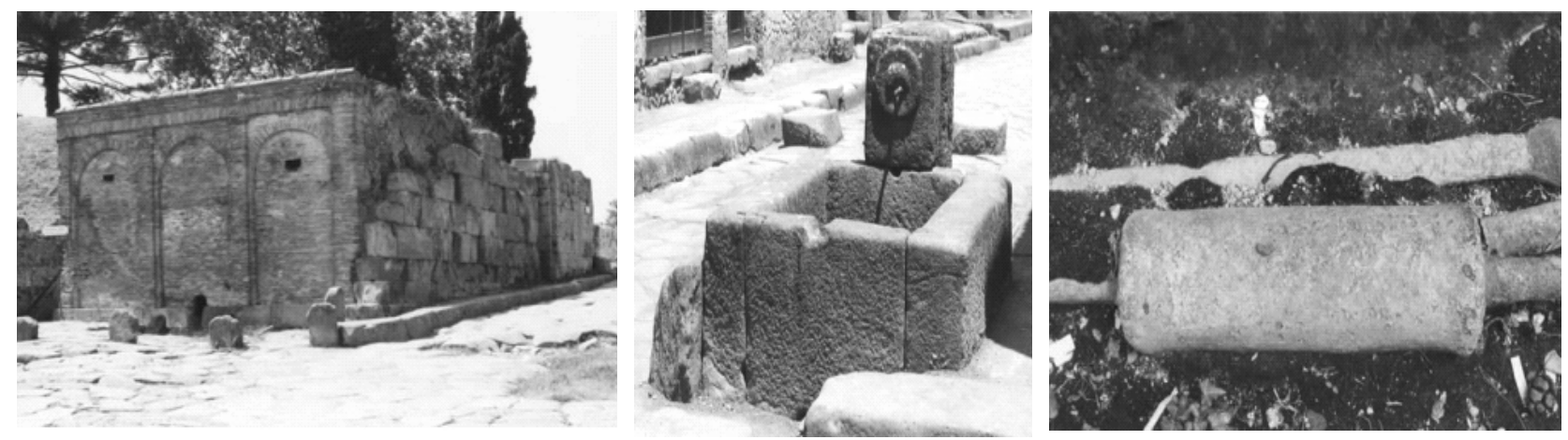

Figure 9 Elements of water supply system at Pompeii: (left) castellum divisorium at Porta Vesuvii housed in the large brick building; (middle) public fountain; and (right) lead pipe with enlarged section of junction box. 
The main aqueduct ends at the main castellum, or castellum divisorium. The castellum divisorium is a junction where the main aqueduct ends and the urban distribution system begins (Fig. 9, left). A lead pipe or smaller aqueduct was then used to transport the water from the main castellum to a secondary castellum or water tower when the secondary castellum was raised to the top of a brick pier. From the water tower (secondary castellum) lead pipes were used to branch the supply to individual customers, public fountains for the domestic supply.

Sources of water for Pompeii included wells, cisterns and other reservoirs, and a long-distance water supply line (Crouch, 1993, p. 178). According to Richardson (1988, p. 51) there were no springs within the city of Pompeii. The water table was tapped within Pompeii using wells as deep as $38 \mathrm{~m}$ below the surface (Maiuri, 1931, pp. 546-557). A long distance aqueduct from the hills to the east and northeast also supplied the city. This aqueduct received water from springs at Serino, near Avellino, and then was routed via Sarno around the north side of Mt. Vesuvius to serve Naples and two large cisterns of Cento Camerelle (Baiae) and the Piscina Mirabilis (Misenum). From Sarno a branch aqueduct was routed to Pompeii terminating at the castellum at Porta Vesuvii (Hodge, 1992).

Two approaches to laying out the pipe network were followed: (a) using a main pipe from the secondary castellum with smaller branch pipes attached to serve individual customers, and (b) not using main pipes but using individual pipes laid from the secondary castellum to the individual customer, which was the normal Roman practice (Hodge, 1992, p. 320). Pompeii's water distribution system consisted of pipes along the main streets connecting the main castellum at Porta Vesuvii to the various water towers (secondary castella), from which smaller pipes were placed under the sidewalks and streets and served the various customers. Not all customers had individual lines from a secondary castellum but instead received their supply from taps into the system at their locations.

Two public water fountains placed back to back along a street with water supplied from a secondary castellum at another location are shown in Fig. 9. The public water fountains were placed somewhat evenly around Pompeii, with the radius of each circle in the map being $50 \mathrm{~m}$. The fountains had an overflow weir so that the water would flow into the streets and then into the drainage system. Terracotta pipes were not used in the water distribution system in Pompeii (Jansen, 2001). The lead pipes (Fig. 9, right) in Pompeii are of the same construction and appearance as found in other Roman cities. The water taps found in Pompeii were also similar to those found in other Roman cities. Only a small number of houses had a water pipe that supplied a private bath or basins in the kitchen in the toilet of in the garden. Overflows were drained into cisterns for rainwater.

The households and public buildings both had very interesting systems to collect and store rainwater. Buildings with peaked roofs had gutters along the eaves to collect the rainwater and downspouts to carry the water to the cisterns located under the building. Downspouts were made of terracotta pipes and were often set inside the wall.

\section{CONCLUSION AND DISCUSSION}

Urban hydraulic systems started to develop in the Bronze Age and particularly in the mid-third millennium BC in an area extending from India to Egypt. About the same time advanced urban water technologies were developed in Greece and particularly in the island of Crete where the Minoan civilization was flourishing. These included construction and use of aqueducts, cisterns, wells, fountains, bathrooms and other sanitary facilities, which suggest life style standards close to those of present day. The technology matured and evolved during latter stages of the Greek civilization with a peak at the Hellenistic period, supported by the understanding of natural 
processes and the development of scientific concepts. The Romans developed high engineering skills and were able to expand these technologies on large scale projects throughout their large Empire.

After the fall of the Roman Empire, the concepts of science and technology related to water resources retrogressed. Water supply systems and water sanitation and public health declined in Europe, which entered a period called the Dark Ages. Historical accounts tell of incredibly unsanitary conditions - polluted water, human and animal wastes in the streets, and wastewater thrown out of windows onto people in the streets (Gray, 1940). Various epidemics ravaged Europe. During the same period, several Byzantine sites in Greece and Asia Minor kept a high level of civilization whereas Islamic cultures, on the periphery of Europe, ad religiously mandated high levels of personal hygiene, along with highly developed water supply, sewerage and adequate sanitation systems. Europe acquired again high standards of water supply and sanitation only in the $19^{\text {th }}$ century.

\section{REFERENCES}

Abdel Khaleq, R.A., and Alhaj Ahmed, I. (2007). Rainwater harvesting in ancient civilizations in Jordan, Water Science and Technology (this issue).

Adam J.-P. (1984). La Construction Romaine. Paris, France.

Adams R. (1981). Heartland of Cities: Surveys of Ancient Settlements and Land Use on the Central Floodplain of the Euphrates. University of Chicago Press, Chicago, USA.

Angelakis, A. N. and Spyridakis, S. V. (1996). The status of water resources in Minoan times: A preliminary study, In: A. N. Angelakis, A.S. Issar (Eds.), Diachronic Climatic Impacts on Water Resources with Emphasis on Mediterranean Region, Springer-Verlag, Heidelberg, Germany, pp. 161-191 (Ch. 8).

Angelakis, A. N., Savvakis, Y. M., and Charalampakis, G. (2006). Aqueducts during the Minoan Era, Water Science and Technology (this issue).

Antoniou, G.P. (2007). Lavatories in Ancient Greece. Water Science and Technology (this issue).

Buffet, B. and Evrard, R. (1950). L'Eau Potable a Travers Les Ages, Editions Soledi, Liege, Belgium.

Cadogan, G. (2006). Water management in Minoan Crete, Greece: The two cisterns of one Middle Bronze Age settlement. , Water Science and Technology (this issue).

Crouch D.P. (1993). Water Management in Ancient Greek Cities. Oxford University Press, New York, USA.

Davaras C. (1976). Guide to Cretan Antiquities, forth ed. Eptalofos s.a., Athens, Greece, 1976.

Evans, A. ( 1921-1935). The palace of Minos at Knossos: A comparative account of the successive stages of the early Cretan civilization as illustrated by the discoveries, Vols. I-IV, Macmillan and Co., London, UK. (Reprinted by Biblo and Tannen, New York, USA).

Evans H.B. (1994). Water Distribution in Ancient Rome: The Evidence of Frontius. University of Michigan Press, Ann Arbor, USA.

Fonder, N., and Xanthoulis, S. (2007). Roman Aqueducts and Hydraulic Engineering: Case of Nimes Aqueduct and its Pont du Gard Bridge. Water Science and Technology (this issue).

Gorokhovich Y. (2005). Abandonment of Minoan palaces on Crete in relation to the earthquake induced changes in groundwater supply, Journal of Archaeological Science, 32: 217-222.

Gray, H. F. (1940). Sewerage in Ancient and Medieval Times, Sewage Works Journal, 12 (5), 939 - 946.

Hassan, F. A. (2003). Water management and early civilizations: From cooperation to conflict. In F.A. Hassan, M. Reuss, J. Trottier, C. Bernhardt, A. T. Wolf, J. Mohamed-Katerere, and P. van der Zaag (Eds.), History and future of shared water resources (PCCP Series No. 6). Paris: UNESCO.

Hodge A.T. (1992). Roman Aqueducts and Water Supply. Gerald Duckworth \& Co., Ltd., London, USA.

Jansen, M. (1989). Water Supply and Sewage Disposal at Mohenjo-Daro, World Archaeology, 21(2), The Archaeology of Public Health), pp. 177-192

Jansen G.C.M. (2001). Water pipe systems in the houses of Pompeii. Water Use and Hydraulics in the Roman City. A.O. KoloskiOstrow (Ed.), Archaelogical Institute of America, Colloquia and Conference Papers, No. 3, Kendall/Hunt Publishing Company, Dubuque, USA.

Koutsoyiannis, D., Zarkadoulas, N., Angelakis, A. N., and Tchobanoglous, G. (2007a). Urban water management in Ancient Greece: Legacies and lessons. ASCE, Journal of Water Resources Planning \& Management (in press).

Koutsoyiannis, D., Mamassis, N., and Tegos, A. (2007b). Logical and illogical exegeses of hydrometeorological phenomena in ancient Greece. Water Science and Technology (this issue).

Kretzschmer F. (1966). La Technique Romaine. Brussels, Belgium.

Maiuri A. (1931). Pompeii Pozzi e Condotture d'Acqua...” and “Scoperta di Grandi Conditture in Piomb dell’Acqueducto Urbano”. Notizie degli Scavi di Antichita, 7.

Moody J. (1996). Environmental Archaeology in Northwest Crete”, Journal of Field Archaeology 23: 273- 279.

Morgan M.H. (translator) (1914). Vitruvius, The Ten Books on Architecture. Cambridge, MA, USA.

Müller, S. (1996). Prospection archéologique de la plaine de Mallia, Bulletin de Correspondence Hellénique 120-2 : $921-928$.

Richardson L.Jr. (1988). Pompeii: An Architectural History. John Hopkins University Press, Baltimore, USA. 
Showleh, T. (2007).Water Management in Bronze Age. Greece and Anatolia. Water Science and Technology (this issue).

Tassios, T. P. (2007). Water supply of ancient Greek cities. Water Science and Technology (this issue).

Taylour, W. (1983). The Mycenaeans, Thames and Hudson, London, UK.

Viollet, P. L. (2003). The Predecessors of European Hydraulic Engineers: Minoans of Crete and Mycenaeans of Greece (2100-1200

B.C.). In: A. Armanini, P. Latinopoulos (Theme Eds.) XXX IAHR Congress, Theme E: Linkage Between Education Research and Professional Development in Water Engineering. August 2003, Thessaloniki, Greece, pp.337- 344.

Wulff, H. E. (1968), The Qanats of Iran, Scientific American, April 1968, 94-105. 